\title{
The Inhibitory Effect of Testosterone on Hypothalamic-Pituitary- Adrenal Responses to Stress Is Mediated by the Medial Preoptic Area
}

\author{
Victor Viau and Michael J. Meaney \\ Developmental Neuroendocrinology Laboratory, Douglas Hospital Research Center, Departments of Psychiatry and of \\ Neurology and Neurosurgery, Faculty of Medicine, McGill University, Montréal, Québec, Canada H4H 1R3
}

\begin{abstract}
In gonadectomized (GDX) animals replaced with subcutaneous steroid implants supplying physiological levels of testosterone $(\mathrm{T} ; 1-10 \mathrm{ng} / \mathrm{ml}$ ), the magnitude of adrenocorticotropic hormone (ACTH) and corticosterone (B) responses to restraint was negatively correlated with the level of $T$ replacement, reflecting the inhibitory influence of $\mathrm{T}$ on hypothalamic-pituitary-adrenal (HPA) responses to stress. Although T had no effect on restingstate levels of corticotropin-releasing hormone $(\mathrm{CRH})$ in the median eminence, arginine vasopressin (AVP) levels were significantly lower in GDX animals replaced with higher $T$ levels, and the magnitude of the ACTH response to restraint was strongly correlated with median eminence levels of AVP. High physiological levels of $\mathrm{T}$ increased glucocorticoid receptor binding in the medial preoptic area (MPOA), with no effect on mineralocorticoid receptor binding or on glucocorticoid recep-
\end{abstract}

tor binding in other regions. Crystalline $\mathrm{T}$ or $\mathrm{B}$ implants in the MPOA significantly reduced plasma $A C T H$ and $B$ responses to 10 min of restraint stress compared with cholesterol-implanted controls. Moreover, B or T MPOA implants also decreased resting-state levels of AVP but not $\mathrm{CRH}$ in the median eminence, and these effects were correlated with ACTH responses to restraint. Finally, lesioning the MPOA blocked the inhibitory effects of high peripheral $T$ levels on $A C T H$ and $B$ responses to restraint.

Thus, variations in the magnitude of HPA responses to stress among males are explained in part by individual differences in circulating T levels, and the MPOA is a critical site for this effect via the inhibition of hypophysial AVP.

Key words: stress; testosterone; ACTH; glucocorticoid receptors; arginine vasopressin; medial preoptic area
Most studies examining hypothalamic-pituitary-adrenal (HPA) function have been performed in the male because this gender is believed to represent a comparatively stable gonadal environment. Gonadal activity in the male, however, is indeed subject to variation, as evidenced by marked changes in testosterone (T) release as a function of social and reproductive status and in response to stress. The manner in which such naturally occurring variations in circulating $T$ levels affect HPA function remains unclear. Males typically show reduced adrenocorticotropic hormone (ACTH) and corticosterone (B) responses to stress (Lescoat et al., 1970; Le Mevel et al., 1978, 1979; Kant et al., 1983) compared with that shown in females, an effect that is attributed in part to the inhibitory effects of testosterone $(\mathrm{T})$. Gonadectomized (GDX) males show increased plasma ACTH and B responses to several forms of stress (Viau and Meaney, 1991b; Handa et al., 1994). This effect is reversed with $\mathrm{T}$ or dihydrotestosterone (DHT), the reduced nonaromatizable form of $\mathrm{T}$, indicating an androgen receptor-mediated effect (Viau and Meaney, 1991b; Handa et al., 1994).

Corticotrophs express few if any androgen receptors (Dubois et al., 1978; Thieulant and Duvall, 1985) and minimal aromatase

\footnotetext{
Received May 25, 1995; revised Sept. 19, 1995; accepted Dec. 12, 1995.

This research was supported by a grant from the Natural Sciences and Engineering Research Council of Canada to M.J.M. M.J.M. holds an MRC Scientist Career Award from the Medical Research Council of Canada. V.V. is currently an MRC Fellow in the Laboratory of Neuronal Structure and Function, The Salk Institute for Biological Studies.

Correspondence should be addressed to Michael J. Meaney, Developmental Neuroendocrinology Laboratory, Douglas Hospital Research Center, 6875 La Salle Boulevard, Montréal, Québec, Canada H4H 1R3.

Copyright (C) 1996 Society for Neuroscience $0270-6474 / 96 / 161866-11 \$ 05.00 / 0$
}

activity (McEwen, 1980). Thus, the inhibition of stress-induced ACTH release by androgens is unlikely to be explained by direct actions of $T$ or its estrogen byproducts at the level of the pituitary. Existing studies suggest central effects of gonadal steroids on HPA activity; females show higher bioassayable levels of hypothalamic corticotropin-releasing hormone (CRH) (Hiroshige et al., 1973) and increased levels of CRH mRNA in the paraventricular nucleus (PVN) (Watts and Swanson, 1989). This sex difference reflects a stimulatory effect of estrogen on $\mathrm{CRH}$ synthesis and release; acute elevations in plasma estrogen levels in females increase CRH mRNA and content in the hypothalamus (Bohler, 1990; Viau and Meaney, 1992).

Chronic DHT treatment decreases the stimulatory effects of chronic gonadectomy on CRH immunoreactivity in the PVN of the hypothalamus (Bingaman et al., 1994). Whether this finding reflects changes in CRH activity within the medial dorsal parvocellular region of the PVN, the source of hypophysiotropic $\mathrm{CRH}$, remains to be resolved. Androgen receptors are present within the PVN but are essentially localized to cell types giving rise to descending brainstem and spinal cord projections (Simerly et al., 1990; Zhou et al., 1994). Thus, the central sites at which androgens modulate HPA activity remain elusive.

Handa et al. (1994) reported that decreased ACTH responses to stress after androgen treatment in GDX males are not associated with changes in glucocorticoid receptor binding capacity or affinity in the hippocampus, hypothalamus, and pituitary. Nevertheless, glucocorticoids regulate HPA activity in several brain regions in addition to these target sites (Kovacs and Makara, 1988; Sapolsky et al., 1990; Dallman et al., 1993; Diorio et al., 1993). Thus, T regulation of glucocorticoid feedback and HPA 
activity may involve alterations in glucocorticoid receptor levels outside the hippocampus and hypothalamus.

Thus, we examined the extent to which variations in plasma $T$ levels regulate plasma $\mathrm{ACTH}$ and $\mathrm{B}$ responses to stress in intact adult males and in GDX rats replaced with physiological doses of $\mathrm{T}$, median eminence CRH and arginine vasopressin (AVP) content, and glucocorticoid receptor binding. The results of the latter study directed our attention to the medial preoptic area (MPOA) of the brain. Thus, we also examined the effects of local steroid implants and lesions of this structure on HPA responses to stress. Our findings indicate that subtle differences in plasma $\mathrm{T}$ levels have a significant impact on several elements of the HPA axis, an effect that is mediated in part at the level of the MPOA.

\section{MATERIALS AND METHODS}

Animals. The animals used were male Long-Evans hooded rats (Charles River Canada, St. Constant, Quebec, Canada) weighing $\sim 300 \mathrm{gm}$ at testing. Animals were group-housed (4/cage) with food and drinking water available ad libitum. Room temperature was maintained at $20-22^{\circ} \mathrm{C}$ with a $12 \mathrm{hr}$ light/dark schedule (lights on 8 A.M. to 8 P.M.). Animals were bilaterally gonadectomized and implanted with subcutaneous SILASTIC capsules [0.062 inner diameter (i.d.), 0.125 outer diameter (o.d.); Dow Corning, Midland, MI] filled with crystalline T (Smith et al., 1977). These capsules were designed to provide circulating $T$ levels over a range of $1-7 \mathrm{ng} / \mathrm{ml}$ in a $300 \mathrm{gm}$ rat. HPA activity was studied 2 weeks after castration and implantation of ' $\mathrm{T}$-filled capsules. Hormone measures during restraint were obtained from blood samples collected from an indwelling right jugular vein SILASTIC cannula $(0.025$ i.d., 0.047 o.d.; Dow Corning) that exited from the back of the neck, and blood samples were replaced with an equal volume of normal saline $(0.9 \%)$ via the same route. Four days before testing, animals were anesthetized with the inhalation anesthetic methoxyflurane (Metofane; Pitman-Moore, Washington Crossing, NJ) and implanted with jugular catheters. They were single-housed for the remainder of the study.

Restraint stress experiments. In all cases, restraint was performed between 12 P.M. and 3 P.M. Prestress blood samples were taken from rats within $30 \mathrm{sec}$ of removal from the cage. Animals then were placed immediately into hemicylindrical, ventilated, Plexiglas tubes for a period of $10 \mathrm{~min}$, after which blood was sampled at $0,10,20,30$, and 60 min after stress. Blood samples $(300 \mu \mathrm{l})$ were collected in iced tubes containing 10 $\mu \mathrm{l}$ of EDTA and aprotinin (Trasylol; Miles Canada), centrifuged at 3000 $\times g$ for $10 \mathrm{~min}$, and stored at $-80^{\circ} \mathrm{C}$ until assayed.

In experiments including measurements of median eminence peptide content, animals were given a $4 \mathrm{~d}$ rest period after the termination of stress. At the conclusion of this period, the animals were killed rapidly by decapitation. We removed the median eminence under a dissection microscope (Cuello et al., 1973) by peeling off the pia matter and, while holding the stalk with fine forceps, dissecting the lateral and frontal borders defined by capillary loops. The stalk was then removed, rapidly frozen on dry ice, and stored at $-80^{\circ} \mathrm{C}$.

Corticosteroid receptor binding assays. Animals were killed by decapitation $16 \mathrm{hr}$ after adrenalectomy. Brains were removed quickly and placed on ice, and the hippocampus, hypothalamus, pituitary, frontal cortex, septum, amygdala, and MPOA were dissected and stored at $-80^{\circ} \mathrm{C}$ until assayed. The tissue was homogenized in TEDGM buffer [ $30 \mathrm{~mm}$ Tris, 1 mM EDTA, $1 \mathrm{~mm}$ dithiothreitol, $10 \%(\mathrm{v} / \mathrm{v})$ glycerol, and $10 \mathrm{~mm}$ sodium molybdate, $\mathrm{pH} 7.4]$ and centrifuged at $105,000 \times \mathrm{g}$. Protein concentrations of the supernatants were determined using the method of Bradford (1976). Single-point glucocorticoid receptor hinding assays were performed by incubating $225 \mu \mathrm{l}$ aliquots of the soluble fraction with $150 \mu \mathrm{l}$ of a saturating $10 \mathrm{nM}$ concentration of $\left[{ }^{3} \mathrm{H}\right]$ dexamethasone (DEX) $(88.7$ $\mu \mathrm{Ci} / \mathrm{mmol}$; DuPont NEN, Boston, $\mathrm{M} \Lambda$ ) with or without a 200 -fold excess of the glucocorticoid receptor agonist RU-28362. Mineralocorticoid receptor determinations were performed by incubating the soluble fractions with $150 \mu \mathrm{l}$ of a saturating $7 \mathrm{nM}$ concentration of $\left[{ }^{3} \mathrm{H}\right] \mathrm{B}(88.0 \mu \mathrm{Ci} / \mathrm{mmol})$ (DuPont NEN) with a 25 -fold excess of RU-28362, with or without a 200 -fold excess of aldosterone. After a 24 and $48 \mathrm{hr}$ incubation at $0^{\circ} \mathrm{C}$ for glucocorticoid and mineralocorticoid receptors, respectively, separation of bound from free ligand was performed on Sephadex LH-20 columns, after which the bound fraction was counted as discussed above. The specific binding is expressed as $\mathrm{fmol} / \mathrm{mg}$ protein.

MPOA steroid implants. Cannulae (24-gauge) containing $100 \mu \mathrm{g}$ of pure crystalline $\mathrm{B}$ or $\mathrm{T}$ were bilaterally implanted into the MPOA under pentobarbital anesthesia and tightly secured to the skull with dental acrylic. The following stereotaxic coordinates (from Paxinos and Watson, 1982) were used with bregma as the anterior-posterior (AP) reference to the dura: AP, $0.6 \mathrm{~mm}$; ventral, $8.0 \mathrm{~mm}$, and $\pm 0.7 \mathrm{~mm}$ from the midline. Control animals were implanted with cannulae containing cholesterol (CHOL) as a control for monspecific steroidal effects. In this study, the animals were gonadectomized and replaced with low T levels $(\sim 1 \mathrm{ng} / \mathrm{ml})$ for a 2 week period and tested 1 week after MPOA steroid implantation. After the experiment, the animals were decapitated and the brains were removed to verify cannulae placement.

After testing, the cannulae were removed and weighed, and in each case $\sim 40 \%$ of the steroid remained in the cannulae. This was also verified in a separate group of animals that were implanted bilaterally with cannulae containing $\left[{ }^{3} \mathrm{H}\right] \mathrm{B}$ and unlabeled B $\left(100,000 \mathrm{cpm}\left[{ }^{3} \mathrm{H}\right] \mathrm{B} / 100 \mu \mathrm{g}\right.$ unlabeled B) as described previously (Meaney and McEwen, 1986; Diorio et al., 1993). The animals were killed 1 week after surgery, and $\left[{ }^{3} \mathrm{H}\right] \mathrm{B}$ diffusion was assessed in microdissected tissue (1 $\mathrm{mm}$ punches) obtained from $300 \mu \mathrm{m}$ brain sections and in median eminence, pituitary, and plasma $(1 \mathrm{ml})$ samples. $\left[{ }^{3} \mathrm{H}\right] \mathrm{B}$ was extracted from sonicated tissue samples with $500 \mu \mathrm{l}$ of ethanol at $25^{\circ} \mathrm{C}$. After extraction, the samples were centrifuged at $12,000 \times \mathrm{g}$, and $250 \mu \mathrm{l}$ aliquots of the extract were then counted in $5 \mathrm{ml}$ of scintillation cocktail (Liquiscent, National Diagnostics, Sommerville, NJ). The remaining pellet was resonicated in aqueous solution, and protein concentrations were determined by the method of Bradford (1976).

MPOA lesions. Bilateral electrolytic lesions of the MPOA were made under pentobarbital anesthesia using the same stereotaxic coordinates as described for the lesion studies. Anodal current $(0.5 \mathrm{~mA})$ was passed through a tungsten microelectrode for a $30 \mathrm{sec}$ period. Sham-lesioned animals received the same treatment as the lesioned animals without current flow. Animals were stressed 2 weeks after lesions. After testing, the animals were decapitated and the brains were removed to verify the extent of the MPOA lesions.

Radioimmunoassays. Plasma B $(10 \mu \mathrm{l})$ was measured by radioimmunoassay (RIA) (Krey et al., 1975) with a highly specific B antiserum (B3-163, Endocrine Sciences, Tarzana, CA) and $\left[{ }^{3} \mathrm{H}\right] \mathrm{B}(101 \mathrm{Ci} / \mathrm{mmol}$, DuPont NEN) as tracer. The antiserum cross-reacts slightly with desoxycorticosterone $(\sim 4 \%)$ but not with aldosterone, cortisol, or progesterone $(<1 \%)$. The intra- and interassay coefficients of variation were 8.8 and $10.4 \%$, respectively.

Plasma ACTH $(25 \mu l)$ concentrations were measured by RIA as described previously (Viau and Meaney, 1991a; Viau et al., 1993). Briefly, unextracted plasma was incubated overnight at $4^{\circ} \mathrm{C}$ with a specific ACTH antiserum at a final dilution of 1:120,000 (IgG Corporation, Nashville, I'N) and [ $\left.{ }^{125} 1\right] \mathrm{AC}$ 'IH (Incstar, Stillwater, MN) as tracer $(5000 \mathrm{cpm} / \mathrm{tube})$. The ACTH antibody cross-reacts $100 \%$ with $\mathrm{ACTH}_{1-39}, \mathrm{ACTH}_{1-18}$, and $\mathrm{ACTH}_{1-24}$ but not with $\mathrm{ACTH}_{1-1 \kappa}, \beta$-endorphin, $\alpha$ - and $\beta$-melanocytestimulating hormone, or $\alpha$ - and $\beta$-lipotropin $(<1 \%)$. After $48 \mathrm{hr}$ of additional incubation, precipitation serum (Antibodies, Davis, CA) was added, and bound peptide was obtained by centrifugation at $5000 \times \mathrm{g}$ for $45 \mathrm{~min}$. The detection limit of the assay was $10 \mathrm{pg} / \mathrm{ml}$. The intra- and interassay coefficients of variation were 7.5 and $12.0 \%$, respectively.

Plasma T (25 $\mu$ l) was measured using the RIA kit of ICN Biomedicals (Carson, CA) with [ $\left.{ }^{125} \mathrm{I}\right] \mathrm{T}$ as tracer. The T antibody (solid phase) crossreacts slightly with $5 \alpha$-DHT $(7.8 \%), 5 \alpha$-androstane- $3 \beta, 17 \beta$-diol $(2.2 \%)$, and 11 -oxotestosterone ( $2 \%$ ) but does not cross-react with progesterone, estrogen, or the glucocorticoids (all $<0.01 \%$ ). The detection limit of the assay was $0.6 \mathrm{ng} / \mathrm{ml}$. The intra- and interassay coefficients of variation were 3.5 and $10.0 \%$, respectively.

Plasma-luteinizing hormone ( $\mathrm{LH} ; 75 \mu \mathrm{l})$ was determined by RIA as described previously (Niswender et al., 1968). Briefly, unextracted plasma was incubated at $4^{\circ} \mathrm{C}$ in PBS (pH 7.4) with LH standard (RP-2) and antiserum (rLH-S-10, 1:125,000) obtained from National Institutes of Health, and $\left[{ }^{125} \mathrm{I}\right] \mathrm{LH}$ as tracer $(15,000 \mathrm{cpm} /$ tube $)$. The $\mathrm{LH}$ antibody cross-reacts $100 \%$ with $\mathrm{LH}$ (RP-2) and $6 \%$ with thyroid-stimulating hormone but not with follicle-stimulating hormone, prolactin, or growth lommone (all $<0.2 \%$ ). The detection limit of the assay was $0.02 \mathrm{ng} / \mathrm{ml}$. The intra- and interassay coefficients of variation were 2.0 and $12 \%$, respectively.

For median eminence $\mathrm{CRH}$ and AVP peptide determinations, the tissue fragments were homogenized in $0.1 \mathrm{~N} \mathrm{HCl}$ buffer at $0^{\circ} \mathrm{C}$ containing $0.001 \% \beta$-mercaptoethanol, $0.05 \%$ ascorbic acid, $0.01 \%$ bacitracin, and $0.001 \%$ phenylmethylsulfonyl fluoride at a ratio of $1 \mathrm{ml} /$ median eminence (Vale et al., 1983). A $200 \mu \mathrm{l}$ aliquot was taken for protein determination 

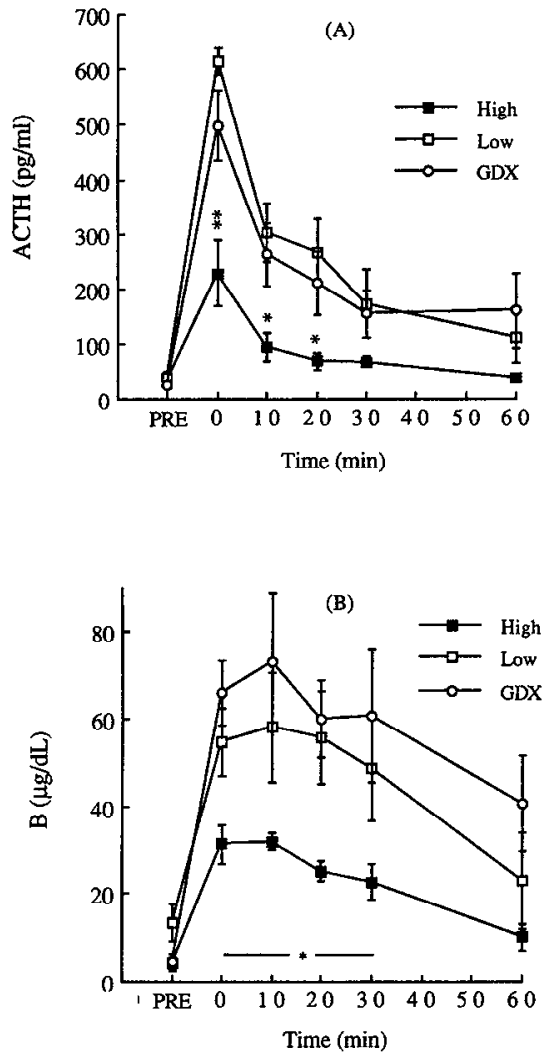

Figure 1. Mean \pm SEM plasma $\mathrm{ACTH}(A)$ and $\mathrm{B}(B)$ values in intact high (filled squares) and low (open squares) $\mathrm{T}$ secretors $(\mathrm{T}=4.0 \pm 0.6$ and $1.2 \pm 0.3 \mathrm{ng} / \mathrm{ml}$, respectively) and in GDX (open circles) rats immediately before $(P R E)$ and after the termination of $10 \mathrm{~min}$ of restraint stress $(n=$ $5 ; 5$ and 6 animals/group, respectively). ${ }^{* *} p<0.01 ;{ }^{*} p<0.05$ versus low $\mathrm{T}$ and GDX animals.

by the method of Bradford (1976). Samples were centrifuged at $12,000 \times$ $g$ for $30 \mathrm{~min}$, after which the supernatants were lyophilized and reconstituted in RIA buffer. CRH and AVP content were measured by RIA using specific antisera and $\left[{ }^{125} \mathrm{I}-\mathrm{Tyr}^{0}\right] \mathrm{CRH}$ and $\left.{ }^{125} \mathrm{I}-\mathrm{Arg}^{8}\right] \mathrm{AVP}$ as tracer, respectively (Peninsula Laboratories, Belmont, CA). The CRH antibody $(1: 48,000)$ cross-reacts $100 \%$ with human/rat $\mathrm{CRH}, 36 \%$ with bovine $\mathrm{CRH}$, and $<0.01 \%$ with ovine $\mathrm{CRH}$ and sauvagine, but it does not cross-react with $\mathrm{LH}$-releasing hormone, $\mathrm{ACTH}$, or $\left[\mathrm{Arg}^{8}\right]$-vasopressin. The AVP antibody $(1: 150,000)$ cross-reacts $100 \%$ with $\left[\mathrm{Arg}^{8}\right]$-vasopressin and $\left[d\left(\mathrm{CH}_{2}\right)_{5}, \mathrm{D}-\mathrm{Ile}^{2}, \mathrm{Ile}^{4}, \mathrm{Arg}^{8}\right]$-vasopressin and $0.8 \%$ with desamino-[D$\mathrm{Arg}^{8}$ ]-vasopressin, but it does not cross-react with LHRH, ACTH, or oxytocin. The detection limit of both assays was $5 \mathrm{pg} / \mathrm{tubc}$. The intra-assay coefficient of variation for both the CRH and the AVP RIAs was $-5.0 \%$, whereas the interassay coefficients were 11.2 and $13.0 \%$, respectively.

Statistical analysis. Unless otherwise stated, the data were analyzed using a two-way ANOVA with Tukey's post hoc tests performed where appropriate. Integrated plasma ACTH and B levels (area under the curve) were calculated using the trapezoidal method (Tallarida and Murray, 1981), which provided an index of total hormone responses to restraint. Integrated ACTH and B values are expressed as $\mathrm{pg} \cdot \mathrm{mg}^{-1} \cdot \mathrm{min}^{-1}$ and $\mu \mathrm{g} \cdot \mathrm{dl}^{-1} \cdot \mathrm{min}^{-1}$, respectively. Regression analyses were performed using the least-squares method.

\section{RESULTS}

\section{HPA responses to restraint in intact and GDX animals}

Intact animals were ranked according to their basal plasma $T$ levels. The median $\mathrm{T}$ value was $1.8 \mathrm{ng} / \mathrm{ml}$. Animals with $\mathrm{T}$ levels less than or greater than this value were grouped as low- or high- $T$ animals, respectively. Peak ACTH and B responses to $10 \mathrm{~min}$ of restraint stress in intact animals with high basal $T$ levels (group mean $=4.0 \pm 0.6 \mathrm{ng} / \mathrm{ml}$ ) were significantly lower than those in
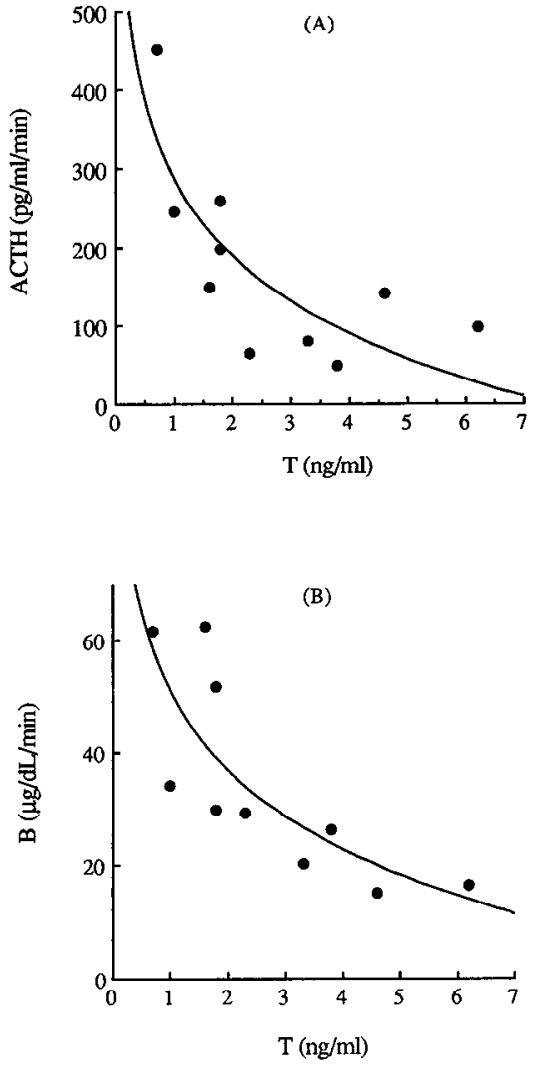

Figure 2. Scattergrams of integrated plasma ACTH $(A)$ and $\mathrm{B}(B)$ responses to $10 \mathrm{~min}$ of restraint stress as a function of individual $\mathrm{T}$ levels in intact animals. $A$, The relationship between $\mathrm{T}$ levels and the integrated ACTH response to restraint was best fit by the equation $y=288.3-330.7$ $\times \log (x) . R$, The integrated $\mathrm{B}$ response to stress was also described by a logarithmic fit: $y=51.2-47.2 \times \log (x)$.

animals with low basal $\mathrm{T}$ levels (group mean $=1.2 \pm 0.3 \mathrm{ng} / \mathrm{ml}$ ) or in GDX male rats (Fig. 1). Interestingly, GDX and intact low-T animals showed comparable $(p>0.05) \mathrm{ACTH}$ and $\mathrm{B}$ responses to restraint (Fig. 1). There were no differences in prestress (basal) levels of plasma ACTH or B as a function of $\mathrm{T}$ (Fig. 1).

Analysis of individual integrated ACTH $\left(\mathrm{pg} \cdot \mathrm{ml}^{-1} \cdot \mathrm{min}^{-1}\right)$ and B $\left(\mu \mathrm{g} \cdot \mathrm{dl}^{-1} \cdot \mathrm{min}^{-1}\right)$ responses to stress in intact animals showed a strong negative correlation $(r=-0.80)$ between prestress levels of $\mathrm{T}$ and the integrated $\mathrm{ACTH}$ and $\mathrm{B}$ response to stress (Fig. 2). The relationship between the integrated $\mathrm{ACTH}$ and $\mathrm{B}$ responses to stress and prestress levels of T was best described by a logarithmic fit $(p<0.01)$. The plasma T levels needed to inhibit ACTH and $B$ release were derived from the line of best fit and the maximal integrated $\Lambda \mathrm{CTH}$ and $\mathrm{B}$ responses to restraint. Based on the plasma $\mathrm{T}$ level corresponding to the half-maximal hormone response to stress, the corresponding $\mathrm{IC}_{50}$ values for $\mathrm{T}$ inhibition of ACTH and B were estimated to be $\sim 2.6$ and $2.9 \mathrm{ng} / \mathrm{ml}$, respectively.

HPA responses to restraint in GDX, T-replaced animals

Plasma $\mathrm{T}$ levels in GDX, T-replaced rats approximated those found in intact animals. GDX, T-replaced animals were ranked according to their plasma $T$ levels. The median $T$ value was 2.6 $\mathrm{ng} / \mathrm{ml}$. Animals with $\mathrm{T}$ levels less than or greater than this value were grouped as low or high GDX, T-replaced animals, respectively. As a group, GDX, high T-replaced $(5.1 \pm 0.6 \mathrm{ng} / \mathrm{ml})$ animals showed significantly lower plasma ACTH $(p<0.01)$ 

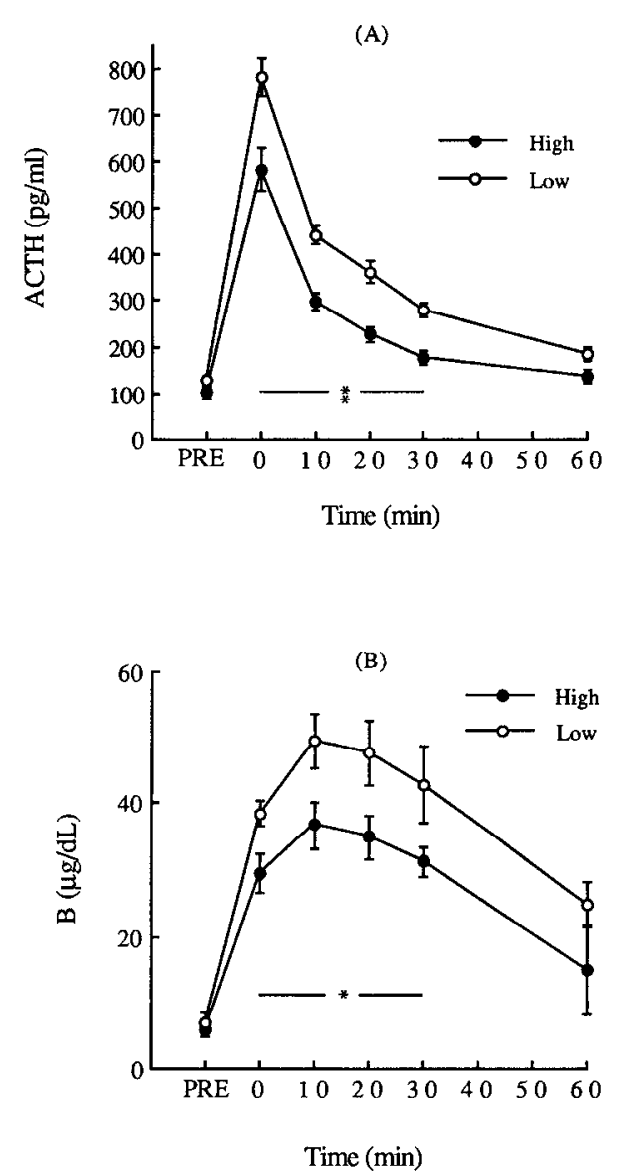

Figure 3. Mean \pm SEM plasma ACTH $(A)$ and B $(B)$ values in GDX high (filled circles) and low (open circles) T-replaced animals $(\mathrm{T}=5.1 \pm$ 0.6 and $1.7 \pm 0.3 \mathrm{ng} / \mathrm{ml}$, respectively) immediately before $(P R E)$ and after the termination of $10 \mathrm{~min}$ of restraint stress ( $n=13$ /group). ${ }^{* *} p<0.01$; $* p<0.05$ versus low GDX, T-replaced animals.

responses to stress compared with animals with low $\mathrm{T}(1.7 \pm 0.3$ $\mathrm{ng} / \mathrm{ml}$ ) replacement levels (Fig. $3 A$ ). Plasma B responses to stress were similarly affected by the level of $T$ replacement, because high T-replaced animals showed significantly lower $\mathrm{B}$ responses to restraint compared with low T-replaced animals (Fig. $3 B$ ). No significant differences were found in prestress basal levels of $\mathrm{ACTH}$ and $\mathrm{B}$ as a function of $\mathrm{T}$ replacement; however, the sampling procedure used here is not adequate to reflect clearly the potential differences in basal ACTH or B levels that fluctuate over a circadian rhythrn. These data simply reflect the absence of any differences in ACTH or B at the time immediately before stress testing.

Analysis of individual HPA responses to restraint in GDX, T-replaced animals further illustrated a relationship between plasma $\mathrm{T}$ levels and the integrated $\mathrm{ACTH}$ and $\mathrm{B}$ responses to stress (Fig. 4). Thus, a strong negative correlation was found between the level of T replacement and the integrated ACTH $(r$ $=-0.79)$ and $\mathrm{B}(r=-0.71)$ responses to stress, described in both cases by a logarithmic fit $(p<0.05)$. The corresponding $\mathrm{IC}_{50}$ values for T inhibition of ACTH and B in GDX animals were $\sim 3.9$ and $3.1 \mathrm{ng} / \mathrm{ml}$, respectively.

\section{ACTH secretagogues in GDX, T-replaced animals}

There were no significant differences in median eminence CRH content as a function of $\mathrm{T}$ replacement (Fig. 5A). T-replacement
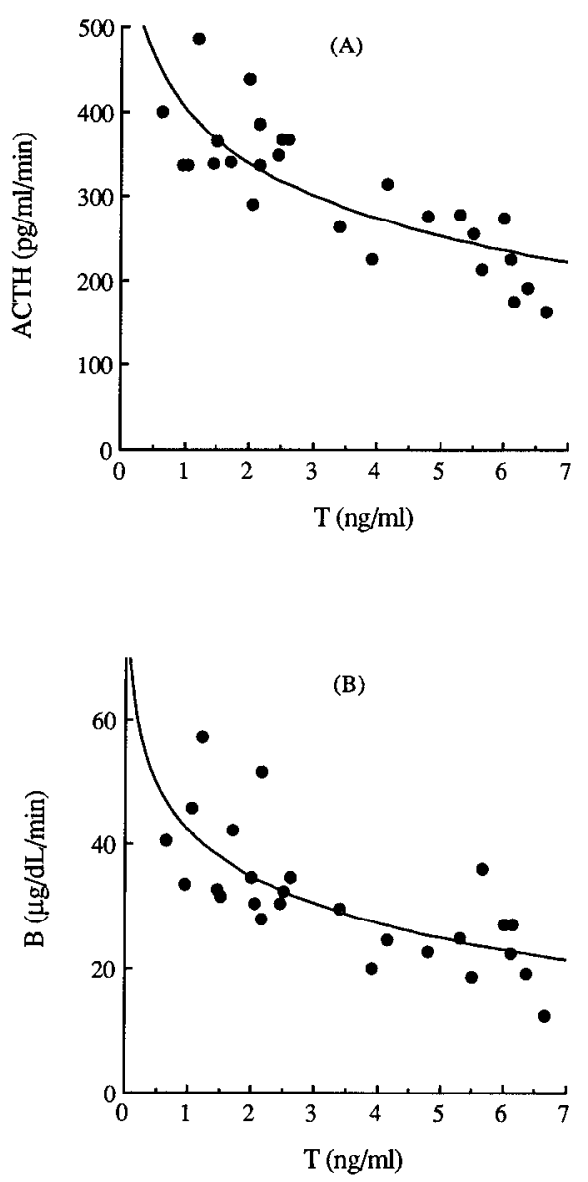

Figure 4. Scattergrams of integrated plasma ACTH $(A)$ and $\mathrm{B}(B)$ levels over $60 \mathrm{~min}$ after $10 \mathrm{~min}$ of restraint stress as a function of individual $\mathrm{T}$ levels in GDX, T-replaced animals. $A$, The relationship between T levels and the integrated $\mathrm{ACTH}$ response to restraint was best fit by the equation $y=403.0-215.0 \times \log (x) . B$, The integrated $B$ response to stress was also described by a logarithmic fit: $y=41.7 .2-23.8 \times \log (x)$.

levels in GDX animals, however, had a marked effect on median eminence AVP content. GDX, high T-replaced animals had significantly lower $(P<0.01)$ resting-state levels of AVP in the median eminence compared with those in low T-replaced animals (Fig. $5 B$ ). Regression analysis revealed a strong negative correlation $(r=-0.80 ; p<0.01)$ between prestress plasma $T$ levels and AVP content in the median eminence (Fig. $6 A$ ). Further analysis revealed a significant correlation $(r=0.70 ; p<0.01)$ between individual resting-state levels of AVP in the median eminence and the integrated ACTH response to restraint (Fig. $6 B$ ). No clear relationship could be determined between individual resting-state levels of CRH and plasma ACTH responses to stress $(r=0.14 ; p$ $>0.05$ ).

\section{Corticosteroid receptor binding in GDX, T-replaced animals}

No significant differences were found in mineralocorticoid receptor binding as a function of $T$ replacement in the areas studied (Fig. 7B). T replacement in GDX animals, however, had a tissuespecific effect on glucocorticoid receptor binding (Fig. 7A). GDX animals with high plasma $T$-replacement levels showed significantly $(p<0.05)$ greater $\left[{ }^{3} \mathrm{H}\right] \mathrm{DEX}$ binding in the MPOA compared with GDX animals with low T-replacement levels. Regression analysis (Fig. 8) showed a strong positive correlation between 
Figure 5. Mcan \pm SEM rcsting-statc median cmincnce lcvels (pg/ $\mu \mathrm{g}$ protein) of CRH $(A)$ and AVP $(B)$ in GDX high (filled bars) and low (open bars) T-replaced animals $(\mathrm{T}=5.1$ \pm 0.6 and $1.7 \pm 0.3 \mathrm{ng} / \mathrm{ml}$, respectively; $n=13$ /group). ${ }^{* * *} p<$ 0.01 versus GDX, low T-replaced animals.
(A)

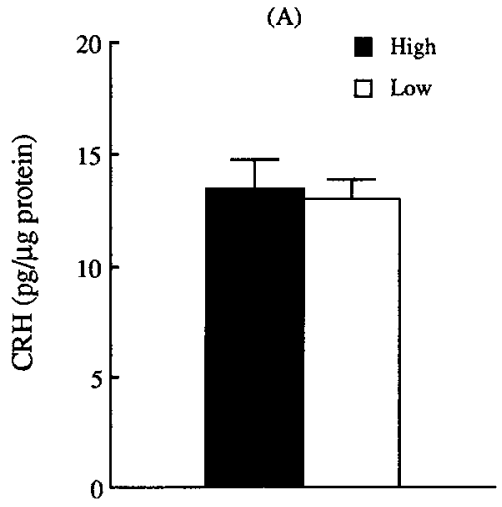

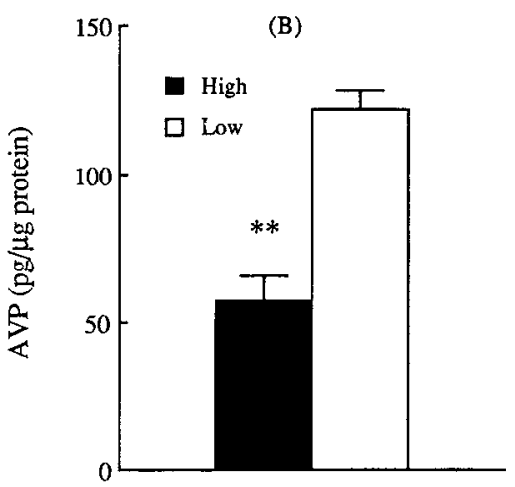

individual plasma T levels and $\left[{ }^{3} \mathrm{H}\right] \mathrm{DEX}$ binding in the MPOA ( $r$ $=0.73 ; p<0.01)$. This relationship was best fit by a linear equation, indicating a graded response in glucocorticoid receptor binding to plasma $\mathrm{T}$ levels. There were no significant effects of $\mathrm{T}$ on glucocorticoid receptor binding levels in any other region studied.

\section{MPOA steroid implants}

Verification of cannula placement indicated that the cannula tips were located within the mediodorsal portion of the MPOA. All animals tested showed bilateral implants in this region. The results of the $\left[{ }^{3} \mathrm{H}\right] \mathrm{B}$ diffusion study indicated that the distribution of radioactivity was confined to the preoptic area. Radioactivity levels in plasma, the bed nucleus of the stria terminalis, supraoptic nucleus (SON), suprachiasmatic nucleus (SCN), PVN, dorsal hippocampus, and median eminence did not significantly exceed background levels. Based on the atlas of Paxinos and Watson (1982), the absence of radioactivity in the SCN indicates that the extent of steroid diffusion was largely contained within a $0.5 \mathrm{~mm}$ area of the cannula tip. This is consistent with previous measures in our laboratory of $\left[{ }^{3} \mathrm{II}\right] \mathrm{B}$ diffusion in the brain (Diorio et al., 1993). Based on the known specific activity of radiolabeled B per cannula (see Materials and Methods), the concentration of $B$ contained within the MPOA punch area was estimated to be $66 \pm$ $7 \mathrm{ng}$. Because $\mathrm{T}$ acts at the level of the MPOA to regulate $\mathrm{LH}$ release, we also measured plasma $\mathrm{LH}$ levels in these animals to verify the efficacy of the implants. Compared with levels in CHOL-implanted animals, plasma LH levels were significantly lower in animals bearing $\mathrm{T}$ implants in the MPOA $(\mathrm{LH}=2.1 \pm$ 0.5 vs $0.5 \pm 0.2 \mathrm{ng} / \mathrm{ml} ; p<0.05$ ).

\section{HPA activity in MPOA steroid-implanted animals}

Plasma ACTH and B responses to restraint were significantly reduced in animals with $B$ and $T$ implants in the MPOA compared with CHOL-treated controls (Fig. 9). Peak ACTH levels were lower in both B- and T-implanted animals compared with those in CHOL animals (Fig. 9A). This difference, however, was only significant $(p<0.05)$ between B and CHOL values. ACTH levels remained significantly lower in B-implanted animals for up to 30 min after restraint. Poststress ACTH levels in T-implanted animals were significantly lower $(p<0.05)$ than in CHOL-implanted animals at 10 and $20 \mathrm{~min}$ (Fig. 9,1). Integrated $\mathrm{ACTH}$ responses were significantly lower $(p<0.01)$ in B- and T-implanted animals compared with those in CHOL-implanted controls (Fig. 10A). The suppression of stress-induced ACTH release by both types of steroid implants is indicated further by the plasma (Fig. $9 B$ ) and integrated (Fig. 10B) B responses to restraint. Thus, B responses to restraint were significantly $(p<0.01)$ reduced in B- and T-implanted animals compared with $\mathrm{CHOL}$ animals. There were no significant differences in prestress basal levels of plasma ACTH and $\mathrm{B}$.

MPOA steroid implants did not alter median eminence $\mathrm{CRH}$ content. Thus, comparable tissue levels of $\mathrm{CRH}$ were observed in animals receiving $\mathrm{B}, \mathrm{T}$, or CHOL MPOA implants (Fig. 11A). Both $\mathrm{T}$ and $\mathrm{B}$ implants, however, decreased median eminence AVP content. AVP peptide levels were significantly lower in animals with $\mathrm{B}(p<0.01)$ and $\mathrm{T}(p<0.05)$ MPOA implants compared with those in CHOL-implanted controls (Fig. 11B). As in our previous study, regression analysis revealed a strong correlation between $\mathrm{ACTH}$ responses to restraint and resting-state
Figure 6. A, Scattergram of median eminence AVP content (pg/ $\mu \mathrm{g}$ protein) as a function of circulating T levels in GDX, T-replaced animals. The relationship between AVP and T was best described by a linear fit: $y=-18.1+156.5 . B$, Scattergram of integrated plasma $\mathrm{ACTH}(\mathrm{pg} / \mathrm{ml} / \mathrm{min})$ responses to stress as a function of resting-state levels of AVP ( $\mathrm{pg} / \mu \mathrm{g}$ protein) in the median eminence. The relationship between AVP and ACTH was best described by a linear fit: $y=1.3 x+184.5$.
(A)
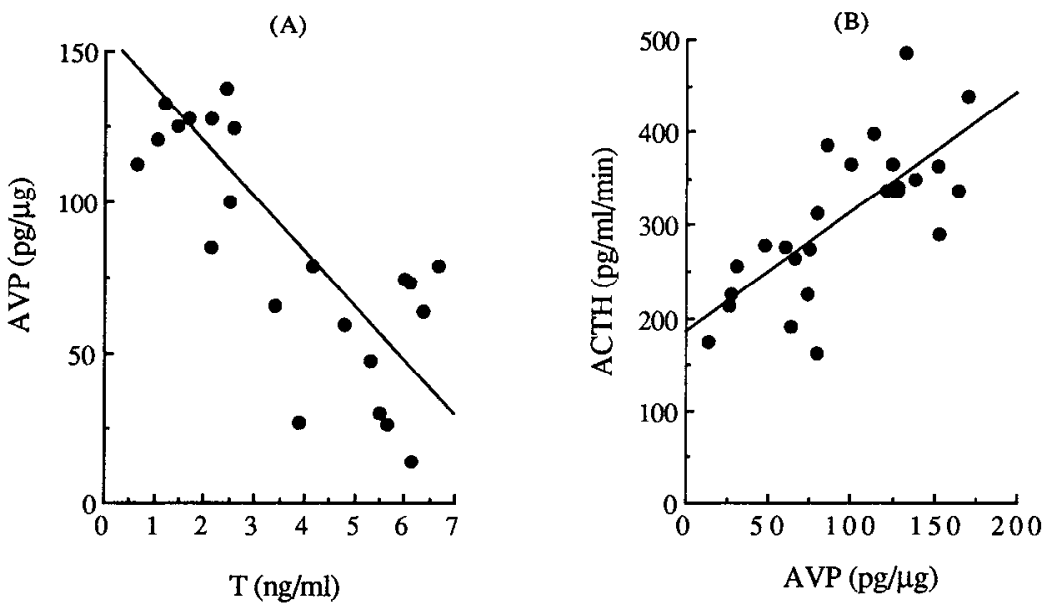

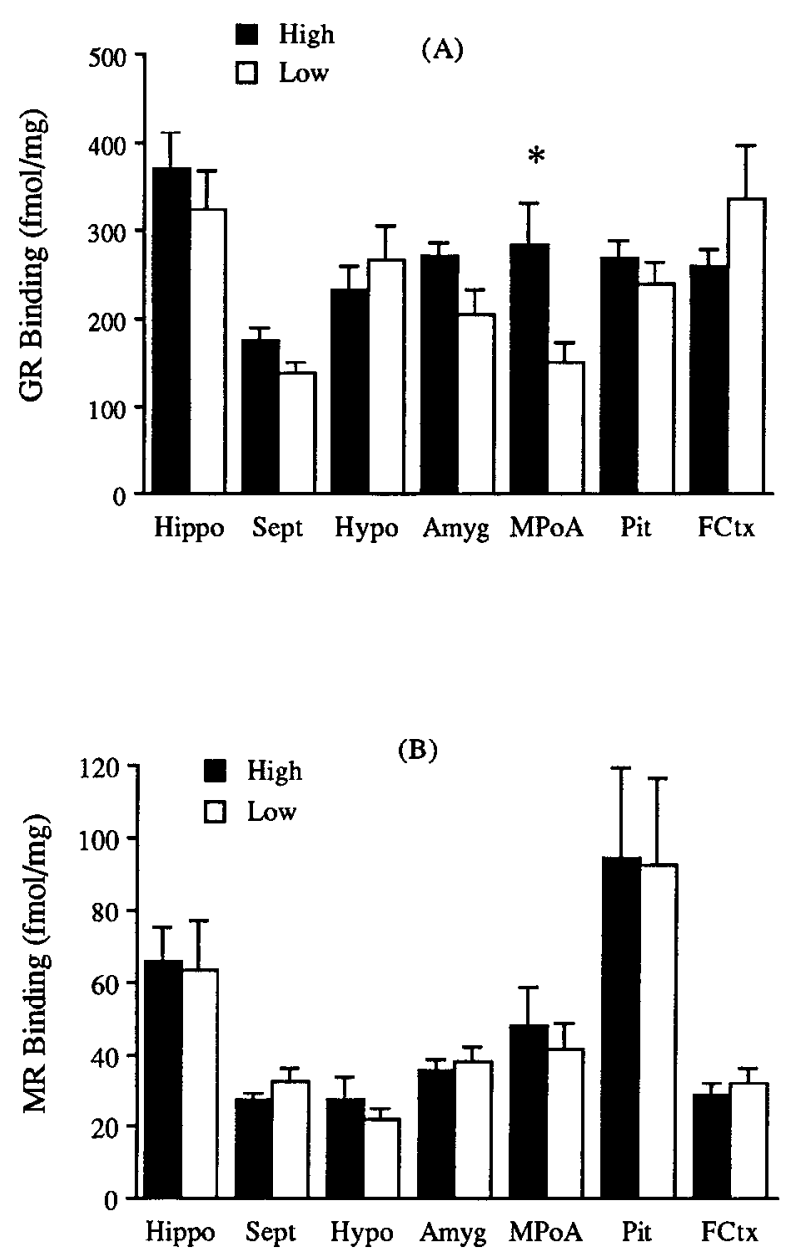

Figure 7. Mean \pm SEM mineralocorticoid $(A)$ and glucocorticoid $(B)$ receptor binding levels ( $\mathrm{fmol} / \mathrm{mg}$ protein) in selected brain regions and in the pituitary in GDX animals replaced with high $(7.6 \pm 0.7 \mathrm{ng} / \mathrm{ml}$; filled bars $)$ and low $(2.5 \pm 0.5 \mathrm{ng} / \mathrm{ml}$; open bars $)$ T levels $(n=6 /$ tissue $) .{ }^{*} p<0.05$ versus low.

median eminence levels of AVP $(r=0.77 ; p<0.01)$ as a function of steroid implantation into the MPOA (Fig. 12).

\section{MPOA lesions}

The extent of the electrolytic lesions was assessed in Nissl-stained sections (Fig. 13). Damage was limited to the mediodorsal portion

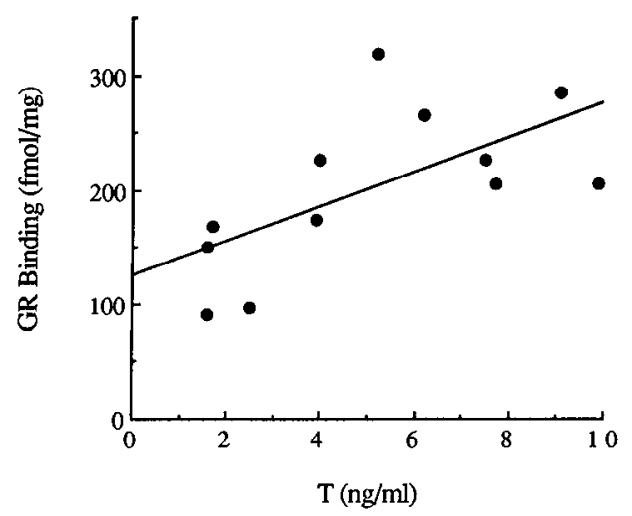

Figure 8. Glucocorticoid receptor binding (fmol/mg protein) in the MPOA as a function of individual plasma T levels in GDX, T-replaced animals. The relationship between $\mathrm{T}$ levels and $\left[{ }^{3} \mathrm{H}\right] \mathrm{DEX}$ binding in the MPOA was best fit by the linear equation $y=14.7 x+119.9$.
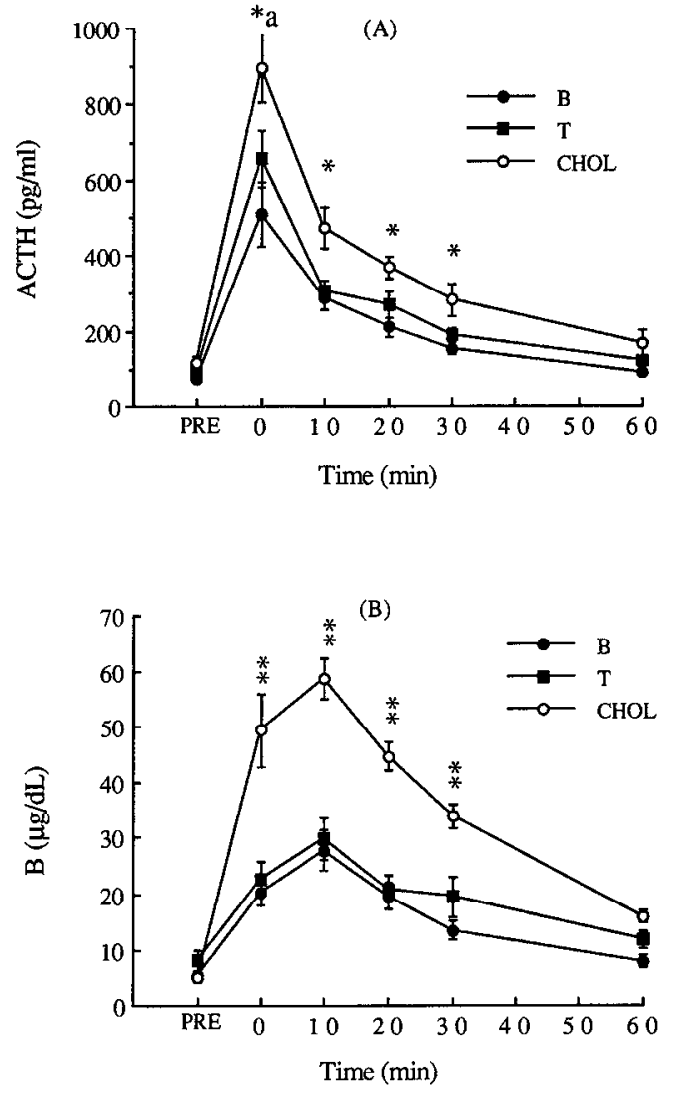

Figure 9. Mean \pm SEM plasma ACTH $(A)$ and $\mathrm{B}(B)$ values in GDX low T-replaced animals with B (filled circles), T (filled squares), and $C H O L$ (open circles) MPOA implants immediately before (PRE) and after the termination of 10 min restraint stress $\left(n=8-9\right.$ animals/group). ${ }^{* *} p<$ $0.01 ;{ }^{*} p<0.05$ versus B and T. ${ }^{*} a, p<0.05$ CHOL versus B.

of the MPOA. Animals showing damage that was not bilateral were excluded from the study. The extent of the damage to the MPOA was also functionally assessed by measuring plasma $\mathrm{LH}$ levels from blood samples taken before stress testing. Plasma LH levels were below detectable limits $(<0.02 \mathrm{ng} / \mathrm{mil})$ in GDX, MPOA-lesioned animals with or without high $\mathrm{T}$ replacement, whereas plasma LH levels in sham-lesioned and control high and low T-replaced GDX animals averaged $0.9 \pm 0.3,0.8 \pm 0.4$, and $1.8 \pm 0.5 \mathrm{ng} / \mathrm{ml}$, respectively.

\section{HPA activity in MPOA-lesioned animals}

Consistent with an inhibitory effect of T on stress-related HPA activity, GDX animals with high T-replacement levels showed significantly $(p<0.01)$ lower plasma ACTH and B responses to restraint compared with low T-replaced animals (compare CTL T and $C T L t$, Fig. 14). Peak ACTH responses to restraint were significantly higher in GDX, MPOA-lesioned animals with $(p<$ $0.05)$ or without high $\mathrm{T}(p<0.01)$ replacement compared with sham-lesioned and control animals provided with high T-replacement (Fig. 14A). Poststress ACTH values in MPOAlesioned animals did not significantly differ as a function of $\mathrm{T}$ replacement (compare $M P O A$ lesion + CHOL and $M P O A$ lesion $+T)$. Moreover, the ACTH response to stress in these animals was comparable ( $p>0.05$ ) with that of GDX animals with low T-replacement levels up to $30 \mathrm{~min}$ after the termination of restraint. Taken together, these findings indicate that MPOA lesions can effectively block the suppressive effects of high periph- 

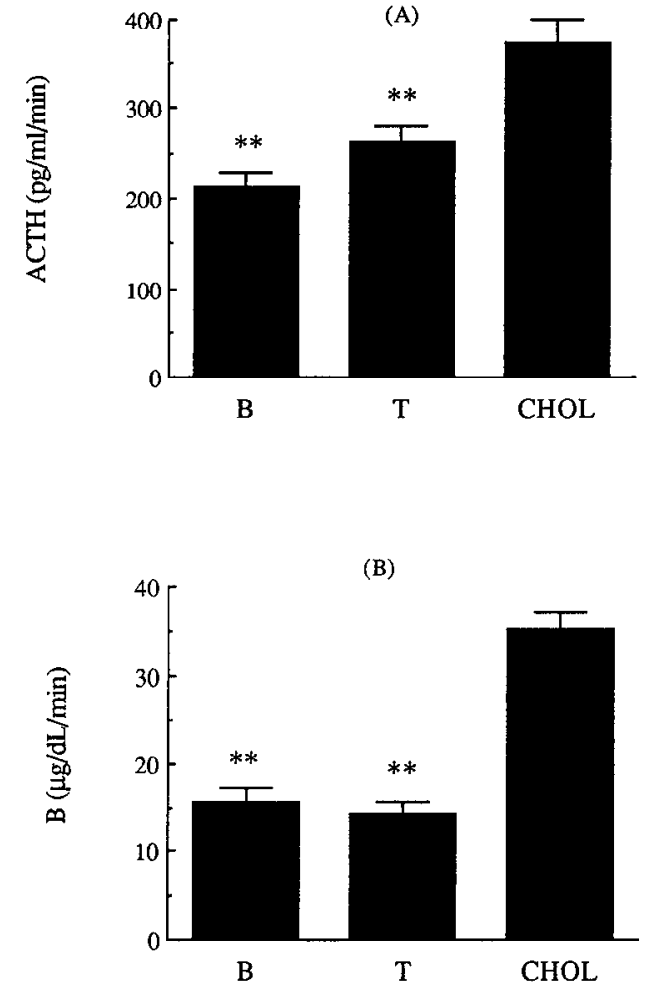

Figure 10. Mean \pm SEM integrated plasma ACTH $(A)$ and $\mathrm{B}(B)$ responses to $10 \mathrm{~min}$ of restraint stress in GDX low T-replaced animals with $B, T$, and $C H O L$ MPOA implants ( $n=8-9$ animals/group). ${ }^{* *} p<$ 0.01 versus CHOL.

eral T levels on plasma ACTH responses to stress. Similar to the pattern of $\mathrm{ACTH}$ release, plasma $\mathrm{B}$ responses to restraint were significantly higher in MPOA-lesioned animals (Fig. 14B). High T replacement in MPOA-lesioned animals also failed to suppress the $\mathrm{B}$ response to stress; comparable plasma $\mathrm{B}$ levels occurred in MPOA-lesioned high T-replaced and control low T-replaced animals. The effects of MPOA lesions on T suppression of HPA activity during stress are illustrated further by the integrated ACTH and B responses to restraint (Fig. 15). Lesions of the MPOA did not seem to alter basal HPA activity, because there were no significant differences in prestress levels of plasma ACTH and $\mathrm{B}$.

\section{DISCUSSION}

Our results indicate that HPA responses to stress are sensitive to naturally occurring variations in circulating $T$ levels. In both intact and GDX, T-replaced animals, ACTH and B responses to restraint were negatively correlated with individual plasma $T$ levels. Note that the estimated $\mathrm{IC}_{50}$ values for $\mathrm{T}$ inhibition of $\mathrm{ACTH}$ and $B$ release in GDX, T-replaced animals were higher than those for intact animals. Similarly, higher T-replacement levels are required to suppress plasma LH levels in castratcd monkcys. Bccausc circulating $\mathrm{T}$ normally fluctuates over a diurnal rhythm, delivery of $T$ in a manner that mimics this diurnal rhythm may be more effective in suppressing stress-related HPA activity than constant levels of $T$ replacement would be.

Plasma T levels transiently increase or decrease after acute stress in rodents and primates (for review, see Rivier and Rivest, 1991). Acute administration of $\mathbf{T}$ to intact animals immediately before restraint stress, however, does not alter $\mathrm{ACTH}$ and $\mathrm{B}$ release during
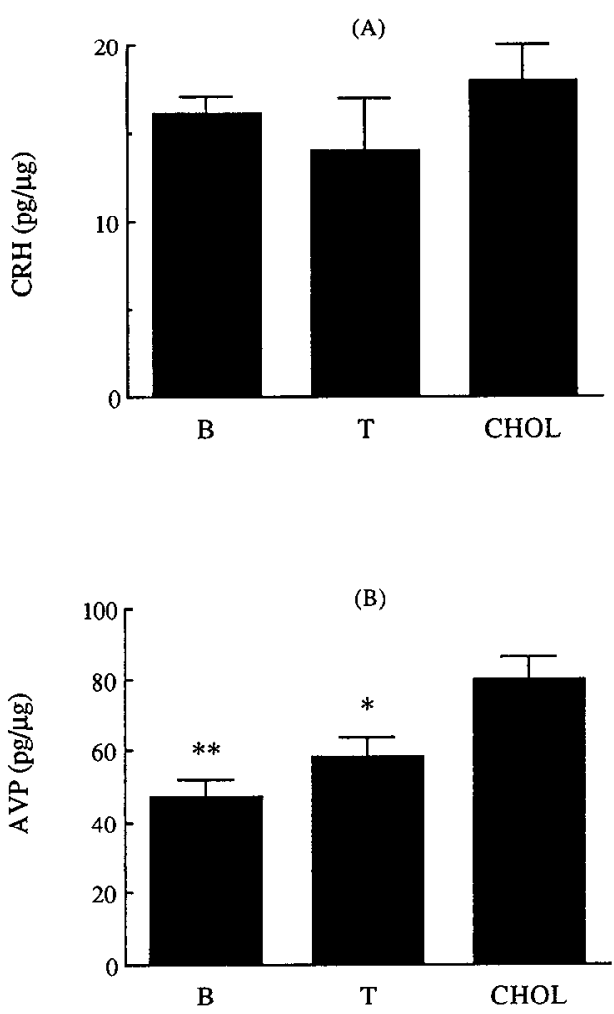

Figure 11. Mean \pm SEM resting-state median eminence levels $(\mathrm{pg} / \mu \mathrm{g}$ protein) of CRH $(A)$ and AVP $(B)$ in GDX low T-replaced animals with $B, T$, and $C H O L$ MPOA implants $\left(n=8-9\right.$ animals/group). ${ }^{* *} p<0.01 ;{ }^{*} p$ $<0.05$ versus $\mathrm{CHOL}$

restraint (our unpublished data). The strong negative correlation between HPA responses to restraint and prestress $\mathrm{T}$ levels in both intact and GDX, T-replaced animals also suggests that individual differences in stress-related HPA activity are regulated by basal T levels. Because GDX, T-replaced animals lack dynamic variations in $\mathrm{T}$, the HPA response to stress is probably regulated by steady-state levels of T-regulated factors, such as hypothalamic AVP, that are involved in ACTH release (see below).

$\mathrm{ACTH}$ and $\mathrm{B}$ responses to restraint were comparable between GDX animals and intact males with low plasma $\mathrm{T}$ levels $(\sim 1$

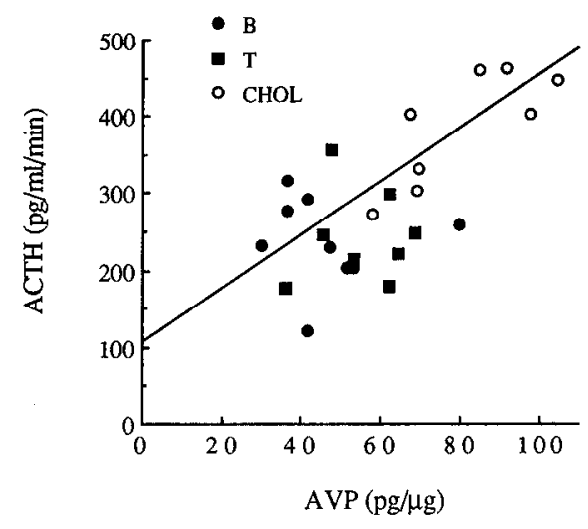

Figure 12. Scattergram of individual integrated plasma ACTH responses to stress as a function of resting-state levels of AVP ( $\mathrm{pg} / \mu \mathrm{g}$ protein) in the median eminence in GDX low T-replaced animals implanted with B (filled circles), $\mathrm{T}$ (filled squares), and CHOL (open circles) in the MPOA. This relationship was best described by the linear equation $y=3.5 x+106.7$. 


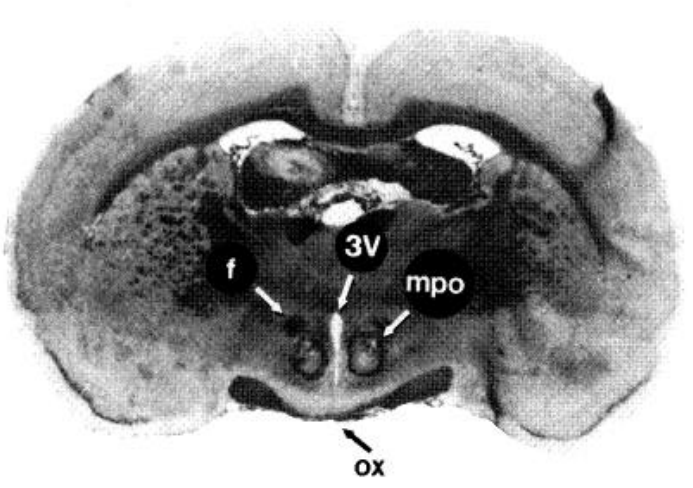

Figure 13. Photomicrograph depicting placement of MPOA lesions. Damage to the MPOA was limited primarily to the mediodorsal part of the MPOA, including the median preoptic nucleus. The optic chiasm was spared in all cases. Damage to the MPOA extended rostrally to the level of the anterior commissure ( $\sim 0.4 \mathrm{~mm}$ caudal to bregma) without involving any other structures. The caudal extent of the MPOA lesions was limited to but did not include the anterior hypothalamic area $(\sim 0.9 \mathrm{~mm}$ caudal to bregma). Analysis was based on the atlas of Paxinos and Watson (1982). $f$, Fornix; mpo, medial preoptic area; $o x$, optic chiasm; $3 V$, third ventricle.

$\mathrm{ng} / \mathrm{ml}$ ). This suggests that a minimum or threshold concentration of circulating $\mathrm{T}$ is required for inhibition of the HPA axis. This is reflected further by the logarithmic relationship observed between plasma $\mathrm{T}$ levels and stress-induced $\mathrm{ACTH}$ and $\mathrm{B}$ release. A similar relationship exists between T-replacement levels and LH levels, at which linear increases in plasma $\mathrm{T}$ levels produce a logarithmic decline in circulating LH concentrations (Dubey et al., 1984). This relationship has been explained by the fact that $\mathrm{T}$ circulates either in a free state or bound to androgen-binding protein $(\mathrm{ABP})$, which limits the access of $\mathrm{T}$ to its target sites (Dubey et al., 1984). Free steroid levels dramatically increase when the capacity of the steroid-binding globulin is exceeded. Thus, linear increases in total plasma $\mathrm{T}$ concentrations over a range that approximates the $K_{\mathrm{d}}$ of the ABP would produce logarithmic increases in free $\mathrm{T}$ (analogous to the relationship between corticosteroid-binding globulin and B; Dallman et al., 1987). This may account for the logarithmic relationship we observed between total plasma T levels and the integrated HPA responses to stress.

The inhibitory effect of T on stress-induced ACTH release seems to involve changes in median eminence levels of AVP. GDX males with high T-replacement levels showed lower resting-state levels of AVP in the median eminence compared with those in GDX, low T-replaced animals, with no effect on $\mathrm{CRH}$ content. Based on the rather static measures used in this study, however, we cannot preclude the possibility of changes in $\mathrm{CRH}$ release in response to restraint stress. Content measures of median eminence AVP provide, for the most part, an index of magnocellular AVP activity. The inhibitory effects of high T-replacement levels in GDX animals on AVP content in the median eminence are consistent with the known inhibitory effects of T on plasma AVP and blood osmolality (Skowsky et al., 1979). Magnocellular AVP constitutes an important source of AVP in pituitary portal plasma (for review, see Antoni, 1993). Several studies reflect a positive relationship between the magnitude of the ACTH response to stress and the level of magnocellular AVP activity (Rittmaster et al., 1987; Irvine et al., 1989; Dohanics et al., 1991; Raff et al., 1991; Aguilera et al., 1993). This is consistent with the strong correlation we observed between median eminence AVP and ACTH responses to stress. Although our measures largely reflect magnocellular AVP, this does not preclude the possibility of T-induced changes in the parvocellular AVP system. Moreover,

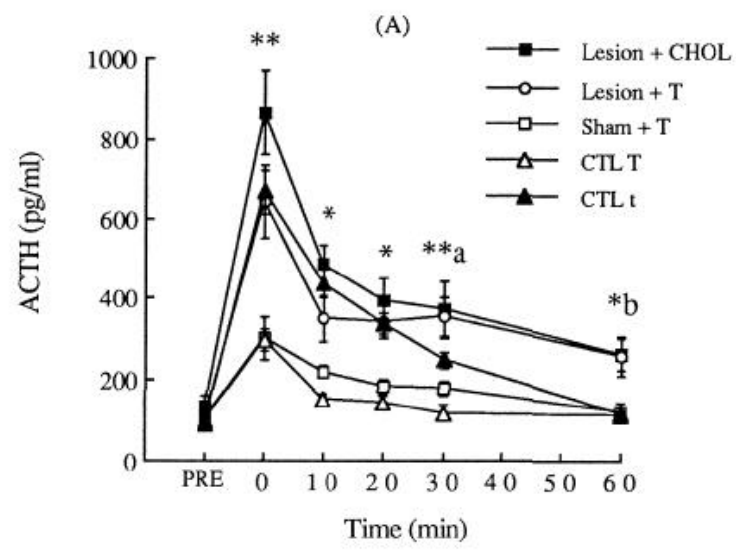

(B)

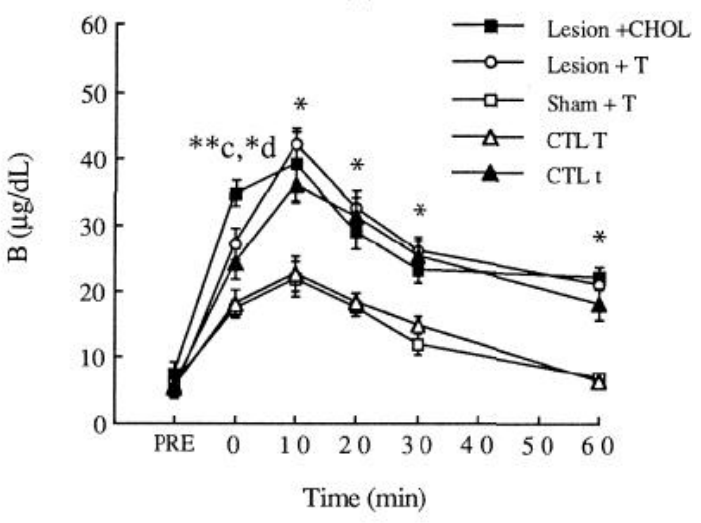

Figure 14. Mean \pm SEM plasma $\mathrm{ACTH}(A)$ and $\mathrm{B}(B)$ values in MPOAlesioned GDX animals without T replacement (Lesion $+\mathrm{CHOL}$; filled squares), in MPOA- and sham-lesioned GDX, high T-replaced animals $[$ Lesion $+T$ (open circles) and Sham $+T$ (open squares), respectively], and in GDX, high (CTL T; open triangles) and low (CTL $t$; filled triangles) T-replaced animals immediately before $(P R E)$ and after the termination of 10 min restraint stress ( $n=5,8,7,6$, and 7 animals/group, respectively). ${ }^{*}{ }^{*} p<0.01 ;{ }^{*} p<0.05 ;$ Lesion $+C H O L$, Lesion $+T$, and $C T L t$ versus Sham $+T$ and CTL T. ${ }^{*}{ }^{*} a, p<0.01 ;{ }^{*} b, p<0.01 ;$ Lesion $+C H O L$ and Lesion $+T$ versus Sham $+T$ and $C T L T$, versus Sham $+T, C T L T$, and $C T L t$, respectively. ${ }^{*} c, p<0.01 ; * d, p<0.05$; Lesion $+C H O L$ versus Sham $+T$ and $C T L T$, versus $C T L t$, respectively.

the correlational analysis could reflect parallel effects of $\mathrm{T}$ on plasma ACTH levels and magnocellular AVP, although the magnitude of the correlation within animals is certainly strong. Thus, at this time these findings simply suggest that $\mathrm{T}$ suppression of stressinduced ACTH release may be mediated by the inhibition of hypophysial AVP.

Glucocorticoid receptor binding in the MPOA was increased in GDX males with high T-replacement levels compared with that in low T-replaced animals. This finding suggests that elevated $\mathrm{T}$ levels might increase the sensitivity of the MPOA to glucocorticoids. Taken together with the inhibitory effects of B implants into the MPOA on plasma ACTH and B responses to restraint, these findings suggest further that $\mathrm{T}$ may inhibit HPA responses to stress by enhancing glucocorticoid feedback at the level of the MPOA.

The data presented here certainly favor the MPOA as a critical site for the effects of T on HPA responses to stress. Plasma ACTH and $\mathrm{B}$ responses to restraint stress were decreased in animals bearing $\mathrm{T}$ implants in the MPOA. Moreover, in MPOA-lesioned 

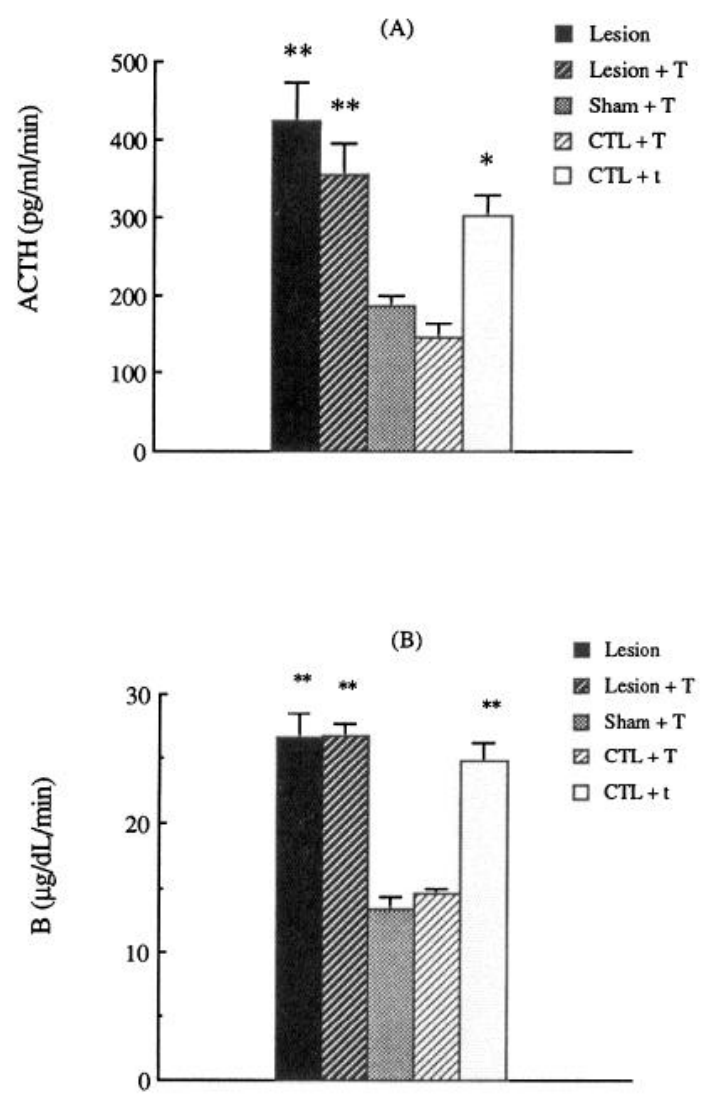

Figure 15. Mean \pm SEM integrated plasma ACTH $(A)$ and $\mathrm{B}(B)$ responses to $10 \mathrm{~min}$ of restraint stress in MPOA-lesioned GDX animals without T replacement (Lesion + CHOL), MPOA- and sham-lesioned GDX high T-replaced animals (Lesion $+T$ and Sham $+T$, respectively), and in GDX, high $(C T L T)$ and low $(C T L t)$ T-replaced animals $(n=5$, $8,7,6$, and 7 animals/group, respectively). ${ }^{*}{ }^{*} p<0.01 ;{ }^{*} p<0.05$; versus Sham $+T$ and $C T L T$.

animals, high peripheral T-replacement levels failed to inhibit $\mathrm{ACTH}$ and $\mathrm{B}$ release during restraint. The actions of both the $\mathrm{B}$ and the T implants into the MPOA on ACTH responses to stress were highly correlated with median eminence AVP levels. These findings suggest that $T$ regulation of the HPA axis at the level of the MPOA may be dependent on circulating B levels.

Basal plasma B levels in male rodents increase during the morning in response to estrogen implants into the MPOA (Telegdy, 1964). Peripheral administration of estrogen in males increases ACTH and B release under basal as well as stressful conditions (Kitay, 1968). In contrast, systemic T or T implants into the MPOA decrease HPA responses to stress. These differences between $T$ and estrogen suggest that the effects of T on HPA activity are mediated via the androgen receptor. This distinction is important, considering the high amount of aromatase activity in the MPOA (Roselli, 1985), and it merits further study using nonaromatizable androgens.

The MPOA sends extensive projections to several regions, including the PVN, the SON, and the internal zone of the median eminence (Swanson, 1976, 1987; Simerly and Swanson, 1988; Cullinan et al., 1993). These projections may explain the effects of the B and T implants in the MPOA on median eminence AVP content. Electrical stimulation of the MPOA increases PVN unit activity and plasma B levels (Redgate and Fahringer, 1973; Saphier and Feldman, 1985, 1986). Furthermore, iontophoretic in- jection of cortisol directly into the MPOA affects the cell firing rate in this region (Papir-Kricheli and Feldman, 1982). Thus, the MPOA is functionally sensitive to glucocorticoids and is in a position to regulate the synthesis and stress-induced release of hypophysiotropic AVP. This is consistent with the effects of B and T MPOA implants on AVP median eminence levels and ACTH responses to restraint.

The MPOA also projects to the BNST and the amygdala (Swanson, 1976, 1987; Palkovits, 1987), structures that innervate the PVN and regulate HPA activity. Indirect pathways from the amygdala to the hypothalamus include the ventral amygdalofugal pathway, the BNST, and the MPOA, which in turn project to both parvocellular and magnocellular divisions of the PVN (for review, see Whitnall, 1993). Because the MPOA receives and reciprocates input from the BNST and amygdala, the MPOA could modulate input to the PVN. This is consistent with the finding that MPOA lesions inhibit the increase in plasma B levels after electrical stimulation of the medial amygdala (Feldman et al., 1990).

$\mathrm{T}$ has marked effects on the morphology of vasopressinergic projections of the BNST and the medial amygdaloid nucleus. Gonadectomy causes a decrease in AVP fiber densities in these regions, which is prevented by $\mathrm{T}$ replacement (De Vries et al., 1984, 1985; Urban et al., 1991). Although these effects are the opposite of the T-dependent changes we observed in median eminence AVP content, intrahypothalamic vasopressinergic pathways seem to regulate the HPA axis negatively. AVP projections from the SCN inhibit unit activity in the PVN and the SON and decrease plasma B levels (Nicoll and Barker et al., 1971; Buijs, 1978; Hoorneman and Buijs, 1982; Hermes et al., 1991; Kalsbeek et al., 1992). This suggests that the inhibitory effects of $\mathrm{T}$ on median eminence AVP content and plasma ACTH responses to stress could be functionally coupled to the positive effects of $\mathrm{T}$ on central AVP activity (i.e., inhibitory vasopressinergic projections to AVP neurons in the PVN). Thus, the effects of T on stressrelated HPA activity may not be exclusive to the MPOA.

Another neurotransmitter that may be involved in the suppressive effects of T on HPA activity is GABA. GABA innervation accounts for more than half of the synaptic inputs to the SON and PVN (Decavel and van den Pol, 1990; Roland and Sawchenko, 1993). GABA input to magnocellular neurons of the SON originates in part from the median preoptic nucleus. Electrical stimulation of the median preoptic nucleus inhibits the activity of AVP-secreting neurons in the SON, and this effect is blocked by

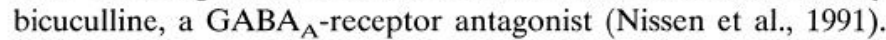
Thus, the inhibitory effects of T implants in the MPOA on median eminence AVP content and HPA responses to stress may be mediated by GABA. DEX suppression of stress-induced B release is blocked with mercaptopropionic acid, an inhibitor of GABA synthesis (Acs and Stark, 1978; Jones et al., 1984). Injection of GABA directly into the median preoptic nucleus decreases plasma cortisol levels in the cat (Krieger and Krieger, 1970). Finally, GABA turnover is decreased in the MPOA after gonadectomy (Grattan et al., 1992). Taken together with our findings of effects of T on glucocorticoid receptor levels in the MPOA and the inhibitory effects of T implants in this region on plasma ACTH responses to restraint, this raises the possibility that T-dependent alterations in glucocorticoid feedback regulation of the HPA axis may involve B- and T-sensitive GABAergic neurons.

Stress studies have been lacking in the female because of the dynamic changes that occur in circulating estrogen and progesterone levels and the difficult task of assessing the relative contributions of these hormones to variation in HPA function. Thus, most 
studies have been performed in the male because it has been assumed that the gonadal axis is less dynamic. Numerous reports, however, have indicated that males of several species show circadian variations in plasma $\mathrm{T}$ levels that are as dynamic as the hormonal changes that occur during the female estrous cycle (Bartke et al., 1973; Kalra and Kalra, 1977; Plymate et al., 1989; Winters et al., 1991). The HPG axis is sensitive to various factors, as evidenced by the changes in $\mathrm{T}$ levels that occur as a function of reproductive experience and social status, as well as response to stress. Indeed, variations in plasma $\mathrm{T}$ levels may mediate, in part, the effects of social status on HPA responses to stress.

\section{REFERENCES}

Acs Z, Stark E (1978) Possible role of $\gamma$-aminobutyric acid synthesis in the mechanism of dexamethasone feedback action. J Endocrinol 77:137-141.

Aguilera G, Lightman SL, Kiss A (1993) Regulation of the hypothalamic-pituitary-adrenal axis during water deprivation. Endocrinology 132:241-248.

Antoni ГA (1993) Vasopressinergic control of pituitary adrenocorticotropin secretion comes of age. Front Neuroendocrinol 14:76-122.

Bartke A, Steele RE, Musto N, Caldwell BV (1973) Fluctuations in plasma testosterone levels in adult male rats and mice. Endocrinology 92:1223-1228

Bingaman EW, Magnuson DJ, Gray TS, Handa RJ (1994) Androgen inhibits the increases in hypothalamic corticotropin-releasing hormone (CRH) and $\mathrm{CRH}$-immunoreactivity following gonadectomy. Neuroendocrinology 59:228-234.

Bohler HCL, Zoeller RT, King JC, Rubin BS, Weber R, Merriam GR (1990) Corticotropin-releasing hormone mRNA is elevated on the afternoon of proestrous in the parvocellular paraventricular nuclei of the female rat. Mol Brain Res 8:259-262.

Bradford M (1976) A rapid and sensitive method for quantitation of microgram quantities of protein utilizing the principle of protein-dye binding. Anal Biochem 72:248-254.

Buijs RM (1978) Intra- and extrahypothalamic vasopressin and oxytocin pathways in the rat. Cell Tissue Res 192:423-435.

Cuello AC, Horn AS, MacKay AVP, Iversen LL (1973) Catecholamines in the median eminence: new evidence for a major noradrenergic input. Nature 243:465.

Cullinan WE, Herman JP, Watson SJ (1993) Ventral subicular interaction with the hypothalamic paraventricular nucleus: evidence for a relay in the bed nucleus of the stria terminalis. J Comp Neurol 332:1-20.

Dallman MF, Akana SF, Cascio CS, Darlington DN, Jacobson L, Levin N (1987) Regulation of ACTH secretion: variations on a theme of $B$. Recent Prog Horm Res 43:113-173.

Dallman MF, Akana SF, Scribner KA, Bradbury MJ, Walker C-D, Strack AM, Cascio CS (1993) Stress, feedback and facilitation in the hypothalamo-pituitary-adrenal axis. J Neuroendocrinology 4:517-526.

Decavel C, van den Pol AN (1990) GABA: a dominant neurotransmitter in the hypothalamus. J Comp Neurol 302:1019-1037.

De Vries GJ, Buijs RM, Sluiter AA (1984) Gonadal hormone actions on the morphology of the vasopressinergic innervation of the adult rat brain. Brain Res 298:141-145.

De Vries GJ, Buijs RM, Van Leeuwen FW, Caffe AR, Swaab DF (1985) The vasopressinergic innervation of the brain in normal and castrated rats. J Comp Neurol 233:236-254.

Diorio D, Viau V, Meaney MJ (1993) The role of the medial prefrontal cortex (cingulate gyrus) in the regulation of hypothalamic-pituitaryadrenal responses to stress. J Neurosci 13:3839-3847.

Dohanics J, Hoffman GE, Verbalis JG (1991) Hyponatremia-induced inhibition of magnocellular neurons causes stressor-selective impairment of stimulated adrenocorticotropin secretion in rats. Endocrinology 128:331-340.

Dubey AK, Herbert J, Abbott DA, Martenz ND (1984) Serum and CSF concentrations of testosterone and $\mathrm{LH}$ related to negative feedback in male rhesus monkeys. Neuroendocrinology 39:176-185.

Dubois PM, Morel G, Forest MG, Dubois MP (1978) Localization of luteinizing hormone ( $\mathrm{LH})$ and testosterone or dihydrotestosterone (DHT) in the gonadotropic cells of the anterior pituitary by using ultracryomicrotomy and immunocytochemistry. Horm Metab Res $10: 250-252$.
Feldman S, Conforti N, Saphier D (1990) The preoptic area and bed nucleus of the stria terminalis are involved in the effects of the amygdala on adrenocortical secretion. Neuroscience 37:775-779.

Grattan DR, Sagrillo CA, Selmanoff M, Ruchkin DS (1992) Effects of castration on GABA turnover in microdissected brain regions in the male rat. Soc Neurosci Abstr 18:456.

Handa RJ, Nunley KM, Lorens SA, Louie JP, McGivern RF, Bollnow MR (1994) Androgen regulation of adrenocorticotropin and corticosterone secretion in the male rat following novelty and foot shock stressors. Physiol Behav 55:117-124.

Hermes MLHJ, Buijs RM, Renaud LP (1991) Electrical stimulation in the suprachiasmatic nucleus depresses the activity in neurons in the hypothalamic paraventricular nucleus region. Soc Neurosci Abstr 17:542.

Hiroshige T, Abe K, Wada S, Kaneko M (1973) Sex difference in circadian periodicity of CRF activity in the rat hypothalamus. Neuroendocrinology 11:306-320.

Hoorneman EMD, Buijs RM (1982) Vasopressin fiber pathways in the rat brain following suprachiasmatic nucleus lesioning. Brain Res 243:235-241.

Irvine CHG, Alexander SL, Donald RA (1989) Effect of osmotic stimulus on the secretion of arginine vasopressin and adrenocorticotropin in the horse. Endocrinology 124:3102-3108.

Jones MT, Gillham B, Altaher ARH, Nicholson SA, Campbell EA, Watts SM, Thody A (1984) Clinical and experimental studies on the role of GABA in the regulation of ACTH secretion: a review. Psychoneuroendocrinology 9:107-123.

Kalra PS, Kalra SP (1977) Circadian periodicities of serum androgens, progesterone, gonadotropins and luteinizing hormone-releasing hormone in male rats: the effects of hypothalamic deafferentation, castration and adrenalectomy. Endocrinology 101:1821-1827.

Kalsbeek A, Buijs RM, van Heerikhuize JJ, Arts M, van der Woude 'IP (1992) Vasopressin-containing neurons of the suprachiasmatic nuclei inhibit corticosterone release. Brain Res 580:62-67.

Kant GJ, Lenox RH, Bunnell BN, Mougey EH, Pennington LL, Meyerhoff JL (1983) Comparison of stress response in male and female rats: pituitary cyclic AMP and plasma prolactin, growth hormone and corticosterone. Psychoneuroendocrinology 8:421-428.

Kitay JI (1968) Effects of estrogen and androgen on the adrenal cortex of the rat. In: Functions of the adrenal cortex (McKerns $\mathrm{KW}$, ed), pp 775-811. New York: Appleton-Century-Crofts.

Kovacs KJ, Makara G (1988) Corticosterone and dexamethasone act at different brain sites to inhibit adrenalectomy-induced adrenocorticotropin hypersecretion. Brain Res 474:205-210.

Krey LC, Lu K, Butler W, Hotchkiss J, Piva F, Knobil E (1975) Surgical disconnections of the medial basal hypothalamus and pituitary function in the rhesus monkey. II. GH and cortisol secretion. Endocrinology 96:1088-1093.

Krieger HP, Krieger DT (1970) Chemical stimulation of the brain: effect on adrenal corticoid release. Am J Physiol 218:1632-1641.

Le Mevel JC, Abitibol S, Beraud G, Maniey J (1978) Dynamic changes in plasma adrenocorticotrophin after neurotropic stress in male and female rats. J Endocrinol 76:359-360.

Le Mevel JC, Abilibol S, Beraud G, Maniey J (1979) Temporal changes in plasma adrenocorticotropin concentration after repeated neurotropic stress in male and female rats. Endocrinology 105:812-817.

Lescoat G, Jego P, Beraud B, Maniey J (1970) Influence de sexe sur les modalités de réponse de l'axe hypothalamo-hypophyso-surrénalien aux agressions emotionelles et somatiques chez le rat. C R Seances Soc Biol Fil 164:2106-2113.

Meaney MJ, McEwen BS (1986) Testosterone implants into the amygdala during the neonatal period masculinize the social play of juvenile female rats. Brain Res 398:324-328.

McEwen BS (1980) Binding and metabolism of sex steroids by the hypothalamic-pituitary unit: physiological implications. Annu Rev Physiol 42:97-110.

Nicoll RA, Barker JL (1971) The pharmacology of recurrent inhibition in the supraoptic neurosecretory system. Brain Res 35:501-511.

Nissen R, Cunningham JT, Allen AM, Renaud LP (1991) Ibotenic acid lesions of median preoptic nucleus do not influence baroreceptorinduced inhibition of suproptic vasopressin-secreting neurons in the rat. Soc Neurosci Abstr 17:473.

Niswender GD, Midgley AR, Monroe SE, Reichert LE (1968) Radioimmunoassay for rat luteinizing hormone with antiovine LH serum and ovine LH ${ }^{131}$ I. Proc Soc Exp Biol Med 128:807-811. 
Palkovits M (1987) Anatomy of neural pathways affecting CRH secretion. Ann NY Acad Sci 512:139-148.

Papir-Kricheli D, Feldman S (1982) Steroid sensitive identified and unidentified neurons in the medial preoptic area of the rat. Neuroscience 7:2793-2800.

Paxinos G, Watson D (1982) The rat brain in stereotaxic coordinates. New York: Academic.

Plymate SR, Tenover IS, Bremner W.I (1989) Circadian variation in testosterone, sex hormone-binding globulin, and calculated non-sex hormone-binding globulin bound testosterone in healthy young and elderly men. J Androl 10:366 371 .

Raff H, Papanek PE, Cowley AW (1991) ACTH and vasopressin responses to insulin-induced hypoglycemia in intact and neurohypophysectomized conscious dogs. Neuroendocrinulogy 53:85-90.

Redgate ES, Fahringer EE (1973) A comparison of the pituitary adrenal activity elicited by electrical stimulation of preoptic, amygdaloid and hypothalamic sites in the rat brain. Neuroendocrinology 12:334-343.

Rittmaster RS, Cutler GB, Gold PW, Brandon DD, Tomai T, Loriaux DL, Chrousos GP (1987) The relationship of saline-induced changes in vasopressin secretion to basal and corticotropin-releasing hormonestimulated adrenocorticotropin and cortisol secretion in man. $\mathbf{J}$ Clin Endocrinol Metab 64:371-376.

Rivier C, Rivest W (1991) Effect of stress on the activity of the hypothalamic-pituitary-gonadal axis: peripheral and central mechanisms. Biol Reprod 45:523-532.

Roland BL, Sawchenko PE (1993) Local origins of some GABAergic projections to the paraventricular and supraoptic nuclei of the hypothalamus in the rat. J Comp Neurol 332:123-143.

Roselli CE, Horton LE, Resko JA (1985) Distribution and regulation of aromatase activity in the rat hypothalamus and limbic system. Endocrinology 117:2471-2477.

Saphier D, Feldman S (1985) Effects of neural stimuli on paraventricular nucleus neurones. Brain Res Bull 14:401-407.

Saphier D, Feldman S (1986) Effects of stimulation of the preoptic area on hypothalamic paraventricular nucleus unit activity and corticosterone secretion in freely moving rats. Neurnendocrinology 42:167-173.

Sapolsky RM, Armanini MP, Packan DR, Sutton SW, Plotsky PM (1990) Glucocorticoid feedback inhibition of adrenocorticotropic hormone secretagogue release. Neuroendocrinology 51:328-336.

Simerly RB, Swanson LW (1988) Projections of the medial preoptic nucleus: a Phaseolus vulgaris leucoagglutinin anterograde tract-tracing study in the rat. J Comp Neurol 270:209-242.

Simerly RB, Chang C, Muramatsu M, Swanson LW (1990) Distribution of androgen and estrogen receptor mRNA-containing cells in the rat brain: an in situ hybridization study. J Comp Neurol 294:76-95.

Skowsky WR, Swan L, Smith P (1979) Effects of sex steroid hormones on arginine vasopressin in intact and castrated male and female rats. Endocrinology 104:105-108.

Smith ER, Damassa DA, Davidson JM (1977) Hormone administration: peripheral and intracranial implants. Methods Psychobiol 3:249-279.
Swanson LW (1976) An autoradiographic study of the efferent connections of the preoptic region in the rat. J Comp Neurol 167:227-256.

Swanson LW (1987) The hypothalamus. In: Handbook of chemical neuroanatomy (Björklund A, Hökfelt T, Swanson LW, eds), pp 1-124. New York: Elsevier.

Tallarida RJ, Murray RB (1981) Area under a curve: Simpson's rule and trapezoidal rule. In: Manual of pharmacological calculations with computer programs, pp 47-49. New York: Springer.

Telegdy GL, Schreiberg G, Endroczi E (1964) Effects of estrogens implanted into the hypothalamus on the activity of the pituitaryadrenocortical system. Acta Physiol Acad Sci Hung 25:229-234.

Thieulant ML, Duvall J (1985) Differential distribution of androgen and estrogen receptors in rat pituitary cell populations separated by centrifugal elutriation. Endocrinology 116:1299-1303.

Urban JH, Miller MA, Dorsa DM (1991) Dexamethasone-induced suppression of vasopressin gene expression in the bed nuclcus of the stria terminalis and medial amygdala is mediated by changes in testosterone. Endocrinology 128:109-116.

Vale W, Vaughan J, Yamamoto G, Bruhn T, Douglas C, Dalton D, Rivier C, Rivier J (1983) Assay for corticotropin releasing factor. In: Methods in enzymology (Conn PM, ed), pp 565-577. New York: Academic.

Viau V, Meaney MJ (1991a) Variations in the hypothalamic-pituitaryadrenal response to stress during the estrous cycle in the rat. Endocrinology 129:2503 2511.

Viau V, Meaney MJ (1991b) Individual differences in the hypothalamicpituitary-adrenal response to stress: relationship to testosterone. Soc Neurosci Abstr 17:542.

Viau V, Meaney MJ (1992) Regulation of ACTH co-secretagogues during the estrous cycle in the rat. Soc Neurosci Abstr 18:643.

Viau V, Plotsky PM, Meaney MJ (1993) Increased plasma ACTH responses to stress in non-handled compared with handled rats require basal levels of corticosterone and are associated with increased levels of ACTH secretagogues in the median eminence. $J$ Neurosci 13:1097-1105.

Watts AG, Swanson LW (1989) Diurnal variations in the content of preprocorticotropin-releasing hormone messenger ribonucleic acids in the hypothalamic paraventricular nucleus of rats of both sexes as measured by in situ hybridization. Endocrinology 125:1734-1738.

Whitnall MH (1993) Regulation of the hypothalamic corticotropinreleasing hormone neurosecretory system. Prog Neurobiol 40:573-629.

Winters SJ, Medhamurthy R, Gay VL, Plant TM (1991) A comparison of moment to moment and diurnal changes in circulating inhibin and testosterone concentrations in male rhesus monkeys. Endocrinology 129:1755-1761.

Zhou L, Blaustein JD, De Vries GJ (1994) Distribution of androgen receptor immunoreactivity in vasopressin- and oxytocinimmunoreactive neurons in the male rat brain. Endocrinology 134: $2622-2627$. 